\title{
Dostęp do turystyki wykluczonych grup społecznych - próba zbadania zjawiska na wybranych przykładach
}

\section{Access to tourism for excluded social groups - exploration of the phenomenon based on selected examples}

\begin{abstract}
Streszczenie: Wykluczenie społeczne jest dziś zjawiskiem wielowymiarowym, przenikającym do wielu aspektów życia. Wykluczenie społeczne (ekskluzja) nie dotyczy jedynie sytuacji, w której jednostki lub grupy społeczne nie mają równego dostępu do m.in. zasobów materialnych, ale coraz częściej związane jest z brakiem możliwości pełnego uczestnictwo w życiu społecznym, ekonomicznym, politycznym i kulturowym w wyniku braku dostępu do zasobów, dóbr i instytucji, ograniczenia praw społecznych oraz deprywacji potrzeb. Termin ten określa również sytuację, w której dana jednostka, będąc członkiem społeczeństwa, nie może normalnie i w pełni realizować swoich potrzeb, zainteresowań, hobby, czy też np. korzystać z usług turystycznych i uczestniczyć w różnorodnych aktywnościach z tym związanych. Jednocześnie każdy z nas ma prawo do uprawiania turystyki - bez żadnych barier, uniedogodnień, bez względu na płeć, wiek, pochodzenie społeczne, orientację seksualną czy też stopień niepełnosprawności. Celem niniejszego artykułu jest próba przeanalizowania problemu, jakim jest wykluczenie z usług turystycznych, na przykładzie wybranych grup społecznych (osób osadzonych, seniorów, dzieci i młodzieży, osób z niepełnosprawnościami) oraz przedstawienie działań wkluczających w tym zakresie po stronie różnych instytucji i organizacji w Polsce i na świecie. Przeprowadzone badania pokazały, że na szczęście dla ww. grup wykluczonych, dostępne są zróżnicowane i skuteczne programy oraz projekty, oferowane przez powołane do tego celu podmioty i organizacje.
\end{abstract}

Abstract: Today, social exclusion is a multidimensional phenomenon that penetrates many aspects of our lives. Social exclusion does not refer only to a situation in which individuals or social groups do not have equal access to, inter alia, material resources, but more and more often it is related to the inability to fully participate in social, economic, political and cultural life as a result of the lack of access to resources, goods and institutions, limitation of social rights and deprivation of needs. This term also describes a situation in which a given individual, being a member of society, cannot naturally fully meet his/her needs, interests or, for example, use tourist services and participate in various related activities. At the same time, each of us has the right to practice tourism without any barriers, regardless of sexual orientation, age, social origin, or degree of disability, etc. The aim of this article is to analyse the problem of exclusion from tourist services based on the example of selected social groups (prisoners, seniors, children and youth, the disabled) and the presentation of inclusive activities of various institutions and organisations in Poland and around the world. The 
conducted research has shown that, fortunately for the surveyed excluded groups, there are various effective programs and projects offered by entities and organisations established for this purpose.

Słowa kluczowe: działania wkluczające; wykluczenia społeczne; wykluczenia w turystyce

Keywords: exclusion in tourism; inclusive actions; social exclusion

Otrzymano: 30 lipca 2021

Received: 30 July 2021

Zaakceptowano: 8 września 2021

Accepted: 8 September 2021

Sugerowana cytacja / Suggested citation

Olszewski-Strzyżowski, D.J. (2021). Dostęp do turystyki wykluczonych grup społecznych - próba zbadania zjawiska na wybranych przykładach. Prace Komisji Geografii Przemysłu Polskiego Towarzystwa Geograficznego, 35(3), 277-294, doi: https://doi.org/10.24917/20801653.353.17

\section{WSTĘP}

Przez wiele lat turystyka należała do potrzeb wyższego rzędu, jednak rozwój społeczno-gospodarczy krajów, wzrost poziomu życia społeczeństw, wzrost znaczenia jakości życia, wzrost dostępności do aktywności turystycznych itp. w ostatnich latach spowodowały, że turystyka przeszła do grupy potrzeb podstawowych. Według Łazarka „turystykę, jako formę zaspokojenia ludzkich potrzeb, zestawia się zwyczajowo z potrzebami wyższego rzędu w piramidzie Maslowa, zwłaszcza z najwyższą potrzebą samorealizacji" (Płocka, 2009: 9). Z roku na rok zwiększa się grono tych, dla których turystyka i jej podejmowanie oraz uprawianie w różnych formach staje się swoistym i nieodzownym elementem życia, stylem życia, sposobem na życie, alternatywnym życiem itp. Ta powszechność i dostępność do usług i do uczestnictwa w turystyce powodują, iż wielu z nas traktuje aktywności turystyczne jako ogólnodostępne dobro, wkluczające nas tym samym w globalna rodzinę turystyczna i zaliczające do grona przedstawicieli gatunku homo turisticus ${ }^{1}$. Według J. Urry’ego „bycie turystą to jeden z wyznaczników bycia nowoczesnym. Nigdzie nie wyjeżdżać to tak, jak nie mieć samochodu, albo ładnego domu. W społeczeństwie nowoczesnym turystyka stała się symbolem statusu" (Urry, 2007: 17).

Jak zauważa Canestrini, ludzkość nigdy nie podróżowała tak dużo, jak w ostatnich dziesięcioleciach dla przyjemności, zainteresowania lub konieczności. Potrzebny jest jednak sprawiedliwy dostęp do usług turystycznych. Zauważalny jest podział i nierówności, a ważna jest w tym względzie m.in. odpowiedzialność społeczna, mądre zarządzanie zasobami środowiskowymi - to strategiczne decyzje nieuchronnie związane z mobilnością turystyczną zarówno ubogich, jak i bogatych (Canestrini, 2016: 50).

Według Winiarskiego „dziś o pozycji społecznej człowieka decyduje już nie tylko rodzaj wykonywanej pracy, lecz także forma spędzania czasu wolnego: poziom rekreacji i konsumpcji" (Winiarski, 2011: 25). Jednak wraz ze wzrostem dostępności pojawia się również coraz większa grupa społecznie wykluczonych z turystyki i pojawiają się w tym zakresie nowe obszary wykluczeń. Należy przypuszczać, że zjawisko to w kolejnych latach będzie się niestety pogłębiać.

${ }^{1}$ Według Bowlesa (2010) do tej grupy zaliczyć możemy osoby bogate, które często podróżują w wolnym czasie dla samej przyjemności i traktują turystykę jako niezbędny element ich życia. 
Celem artykułu jest próba przeanalizowania problemu, jakim jest wykluczenie

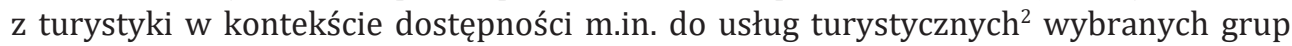
społecznych (osadzonych, seniorów, dzieci i młodzieży, osób z niepełnosprawnościami) oraz przedstawienie działań wkluczających w tym zakresie po stronie różnych organizacji i instytucji. Przykłady wskazane w tekście dotyczą Polski, jak również wybranych krajów na świecie.

\section{POJĘCIE WYKLUCZENIA SPOŁECZNEGO ORAZ WYKLUCZENIA Z TURYSTYKI I USŁUG TURYSTYCZNYCH}

Pojęcie wykluczenia społecznego jest terminem wielowymiarowym (marginalizacja, margines społeczny, ekskluzja) i świadczy o braku zaspokojenia podstawowych potrzeb życiowych człowieka, potrzeb społecznych oraz braku uczestnictwa jednostki w kluczowych aspektach życia społecznego (Golinowska, Broda-Wysocki, 2005: 32).

Wykluczenie jest bardzo dynamicznym procesem, który:

- często spowodowany jest brakiem zasobów;

- prowadzi do sytuacji wielowymiarowej deprywacji o różnych stopniach natężenia;

- charakteryzuje się deficytami uczestnictwa (o różnym stopniu natężenia) w głównym nurcie społeczeństwa i dostępu do zasadniczych systemów społecznych (rynek pracy, zabezpieczenie społeczne, edukacja, opieka medyczna, turystyka);

- może oznaczać zerwanie więzi z rodziną i ze społeczeństwem;

- może powodować utratę poczucia tożsamości i celu w życiu;

- wiąże się z pozbawieniem lub nierealizowaniem uprawnień socjalnych (Łuszczyńska, 2011: 178).

W dokumencie strategicznym Ministerstwa Gospodarki, Pracy i Polityki Społecznej wykluczenie społeczne określa się jako „brak lub ograniczenie możliwości uczestnictwa, wpływania i korzystania z podstawowych instytucji publicznych i rynków, które powinny być dostępne dla wszystkich. To sytuacja uniemożliwiająca lub znacznie utrudniająca jednostce lub grupie, zgodne z prawem pełnienie ról społecznych, korzystanie dóbr publicznych i infrastruktury społecznej, gromadzenie zasobów i zdobywanie dochodów w godny sposób (Ministerstwo Gospodarki, Pracy i Polityki Społecznej, 2003: 21-22).

Według Olszewskiego-Strzyżowskiego najbardziej narażone na wykluczenie społeczne są:

- osoby niepełnosprawne,

- kobiety samotnie wychowujące dzieci,

- ofiary patologii życia rodzinnego,

- osoby chore psychicznie,

- osoby o niskich kwalifikacjach zawodowych,

- osoby starsze,

- osoby samotne,

${ }^{2}$ Usługi turystyczne to m.in. wszystkie niezbędne czynności obejmujące i związane z każdym etapem podróży: przygotowaniem się do podróży, dojazdem do miejsca docelowego, pobytem w wybranym miejscu (destynacji) i z powrotem do miejsca zamieszkania, określone Ustawą z dnia 24 listopada 2017 r. o imprezach turystycznych i powiązanych usługach turystycznych (Dz.U. z 2017 r. poz. 2361). 
- bezdomni,

- długotrwale bezrobotni,

- dzieci i młodzież ze środowisk zaniedbanych i patologicznych,

- osoby będące imigrantami oraz członkowie mniejszości narodowych,

- osoby homoseksualne,

- osoby osadzone lub opuszczające zakłady karne i poprawcze

- osoby uzależnione od alkoholu i narkotyków (Olszewski-Strzyżowski, 2017: 63-67).

Problem wykluczenia społecznego istnieje na całym świecie i w różnym stopniu dotyka kraje ubogie, jak i te bogate, wysoko rozwinięte. Na przykład w Hiszpanii,,marginalizacja dotyczy tych procesów, które są ignorowane przez wiele jednostek i grup i spychane na margines polityczny wielu ludzi ze względu na bezdomność, wiek, status zatrudnienia, język, umiejętności, rasę i religię. Zjawisko grup zmarginalizowanych jest stosunkowo nowym zjawiskiem w tym kraju i staje się jedną z najważniejszych cech charakterystycznych w zakresie transformacji społecznej (np. w aresztach, wśród imigrantów, osób ubogich, kobiet, narkomanów, młodzieży szkolnej itp.)" (Olszewski-Strzyżowski, 2017: 63-67). Problem występuje również w krajach członkowskich Unii Europejskiej, gdzie pomimo ogólnej zamożności, ubóstwo i wykluczenie społeczne utrzymywało się na wysokim poziomie (ok. 25,5\%) (Raczkowska, Gruziel, 2018: 8). Polska jest krajem, w którym od lat wykluczenie społeczne utrzymuje się na średnim poziomie. W roku 2008 zagrożonych ubóstwem lub wykluczeniem było w Polsce ok. 31\% osób (11,5 mln osób), w roku 2011 - 27,2\%, a w roku 2016 - 26\% (Becker-Pestka, Kubiński, Łojko, 2017: 23-33).

Pomimo tego, że wszystkie aspekty życia społecznego powinny być ogólnodostępne dla każdego z nas, istnieje wiele czynników, które sprawiają, że ludzie nie mogą w pełni uczestniczyć w życiu społecznym, jak i w jego poszczególnych dziedzinach, bądź jest to bardzo utrudnione. Uniemożliwia im to m.in. spełnianie własnych potrzeb, rozwijanie zainteresowań i hobby czy osiąganie celów życiowych. Dlatego coraz częściej te problemy zauważa się również w turystyce (usługach turystycznych).

Zgodnie z zapisami Globalnego Kodeksu Etyki w Turystyce (ang. Global Code of Ethics For Tourism), każdy z nas z ma prawo do turystyki i usług turystycznych, a mianowicie:

- potwierdza się prawo wszystkich do turystyki i swobody przemieszczania się w celach turystycznych;

- ludzie na całym świecie mają jednakowe prawo do bezpośredniego i osobistego odkrywania i cieszenia się z bogactw naszej planety. Coraz szersze uczestnictwo w turystyce krajowej i zagranicznej należy postrzegać jako jeden z najlepszych sposobów wykorzystywania stale zwiększającego się czasu wolnego, toteż nie należy stawiać przeszkód na drodze tego uczestnictwa;

- wspierany jest światowy, równoprawny, odpowiedzialny i trwały porządek turystyczny, który jest z korzyścią dla wszystkich części społeczeństw, w ramach otwartej i konkurencyjnej rynkowej gospodarki światowej;

- promowana jest odpowiedzialna, zrównoważona i ogólnie dostępna turystyka w ramach powszechnego prawa do wypoczynku i podróżowania, przy poszanowaniu wyborów społeczeństw wszystkich narodów w tym zakresie;

- działalność turystyczna winna przestrzegać równości kobiet i mężczyzn, zapewniać poszanowanie praw człowieka, w szczególności zaś chronić te odnoszące się 
do najsłabszych grup, a więc dzieci, osób starszych, niepełnosprawnych, mniejszości etnicznych, rdzennej ludności;

- popierana i wspierana jest zwłaszcza turystyka rodzinna, młodzieżowa, studencka oraz dla osób starszych i niepełnosprawnych (General Assembly of the World Tourism Organization, 1999: 4-7).

Niestety zjawisko wykluczeń z usług turystycznych dotyka coraz większą liczbę obywateli z krajów członkowskich Unii Europejskiej. Jak zauważa Alejziak, analizując zjawisko wykluczenia społecznego w krajach UE, nie należy zapominać o problemie dostępności do wyjazdów turystycznych (Alejziak, 2011: 21). D’Ambrosio i Gradin wśród wskaźników charakteryzujących zjawisko wykluczenia społecznego w UE wskazują na brak dostępności do usług turystycznych, umieszczając te potrzeby w kategorii „potrzeb podstawowych". Według autorów, osoby wykluczone to te żyjące w gospodarstwach domowych, których nie stać na m.in. spędzenie choć tygodnia wakacji poza domem (D'Ambrosio, Gradin, 2003: 80). UE promuje w związku z tym hasło „TURYSTYKA DLA WSZYSTKICH" (Europejska Konferencja Ministerialna, 2001), zaznaczając jednocześnie, że turystyka jest „prawem powszechnym, które powinniśmy starać się zapewnić wszystkim osobom" (Opinia Europejskiego Komitetu Ekonomiczno-Społecznego..., 2006: 3) oraz że, „otwarcie granic wewnętrznych pomiędzy państwami członkowskimi niesie wymierne korzyści dla zwykłych ludzi, którzy teraz mogą podróżować swobodnie, bez kontroli granicznych" (Europa w 12 lekcjach, 2006: 45).

Charakterystyczne wykluczenia (inkluzje) z uprawiania turystyki występują w przypadku wszystkich typów wyjazdów turystycznych i usług turystycznych (określanych często jako bariery, ograniczenia lub czynniki ryzyka $w$ turystyce). Jak zauważa Olszewski-Strzyżowski, mamy wtedy do czynienia z taką sytuację, podczas której dana jednostka będąca członkiem społeczeństwa nie może normalnie uczestniczyć w działaniach obywatelskich, realizować w pełni swoich potrzeb, zainteresowań czy też podejmować aktywności fizycznych, w tym także aktywności turystycznych (Olszewski-Strzyżowski, 2017: 63-67).

Alejziak określa bariery w usługach turystycznych czy też przyczyny nieuczestniczenia w wyjazdach turystycznych jako inhibitory, tj. „czynniki, które hamują proces kształtowania się i podejmowania aktywności turystycznej, prowadząc w danym momencie do braku wyjazdu, choć nie wykluczając podjęcia tej aktywności w przyszłości" (Alejziak, 2007: 63). Większość inhibitorów blokuje aktywność turystyczną w określonym przedziale czasu, aczkolwiek istnieją również inhibitory stałe, takie jak głęboka niepełnosprawność lub ograniczona mobilność osób starszych. Autor wyróżnia główne czynniki ryzyka w turystyce:

- ryzyko polityczne (terroryzm, niestabilna sytuacja polityczna, wojny, konflikty militarne);

- ryzyko środowiskowe (klęski żywiołowe);

- ryzyko zdrowotne (brak dostępu do opieki medycznej, zdrowej żywności i czystej wody);

- ryzyko związane z planowaniem (niesolidni organizatorzy, niesolidne linie lotnicze);

- ryzyko utraty mienia (kradzieże, zagubienie bagażu) (Alejziak, 2007: 63). Gracz i Sankowski wskazują na inne bariery ograniczające dostęp do turystyki:

a) bariery zewnętrzne - pozaidywidualne (brak wolnego czasu, problemy organizacyjne i warunki atmosferyczne); 
b) osobowościowe - indywidualne (problemy z podejmowaniem decyzji, niskie poczucie wartości, negatywne nastawienie wobec estetyki ciała, niski poziom samokontroli, ograniczona mobilność (ruchliwość) lub brak pozytywnej postawy prozdrowotnej) (Gracz, Sankowski, 2001: 254).

Natomiast Goeldner i Ritchie do głównych ograniczeń w podróżowaniu zaliczają:

- koszty: sytuacja materialna jest zwykle kluczowym czynnikiem warunkującym uczestnictwo w turystyce;

- brak wolnego czasu: aby uczestniczyć w turystyce, konieczne jest dysponowanie czasem wolnym;

- ograniczenia zdrowotne: ograniczają one w sposób zdecydowany dostęp do turystyki (zwłaszcza osoby niepełnosprawne i seniorzy);

- czynniki rodzinne: niemożność podjęcia wyjazdu turystycznego przez innych członków rodziny, nad którymi musimy sprawować opiekę bądź bez których nie chcemy uczestniczyć w wyjeździe oraz brak osoby, która mogłaby towarzyszyć w wyjeździe;

- obawa o bezpieczeństwo: zdarzenia wywołane przez siły natury bądź spowodowane przez działania człowieka, np. ataki terrorystyczne, konflikty zbrojne, konflikty religijne, klęski żywiołowe, kryzysy ekonomiczne, zagrożenia zdrowotne;

- brak zainteresowania: zainteresowanie innymi sposobami spędzania czasu wolnego niż wyjazdy turystyczne (Goeldner, Ritchie, 2003: 132).

Poniżej przedstawiono autorską propozycję (rycina 1) systematyzacji przyczyn wykluczeń ze społecznego dostępu do usług turystycznych, uwzględniającą następujące przypadki braku dostępu do: a) usług turystycznych (dotyczy to możliwości uczestniczenia w aktywnościach turystycznych wszelkim grupom społecznym, a uwarunkowane m.in. polityką państw, miejscem zamieszkania turysty, biedą, niepełnosprawnością itp.); b) destynacji turystycznych przez różne grupy społeczne, a uwarunkowane m.in. przez dostępność komunikacyjną, prowadzoną politykę państw, konflikty zbrojne i społeczne oraz c) zatrudnienia $w$ turystyce, uwarunkowane m.in. brakiem ofert dla absolwentów kierunków turystycznych, specyfiką usług turystycznych, tj. sezonowością pracy.

\section{PRZYKŁADY SPOŁECZNYCH GRUP WYKLUCZONYCH ORAZ WYBRANE DZIAŁANIA WKLUCZAJĄCE JE W OGÓLNY NURT DOSTĘPNOŚCI DO USŁUG TURYSTYCZNYCH}

Poniżej przedstawiono wybrane grupy społeczne (osoby osadzone, seniorzy, osoby z niepełnosprawnościami oraz dzieci i młodzież), które wykluczone są z dostępności do usług turystycznych. Na każdą z ww. grup wpływ mają (w różnym stopniu i nasileniu) wskazane na rycinie 1. czynniki determinujące ich dostęp do turystyki. Działaniami wkluczającymi badane grupy mogą być m.in. programy podejmowane przez instytucje i organizacje działające na różnych szczeblach (rządowych, regionalnych i lokalnych).

\section{Osoby osadzone}

Jak zauważa Poklek, „poprawa atmosfery panującej w jednostkach penitencjarnych oraz racjonalne zagospodarowanie czasu wolnego poprzez zajęcia ruchowe nabrało szczególnego znaczenia wskutek systematycznego zmniejszania się możliwości 


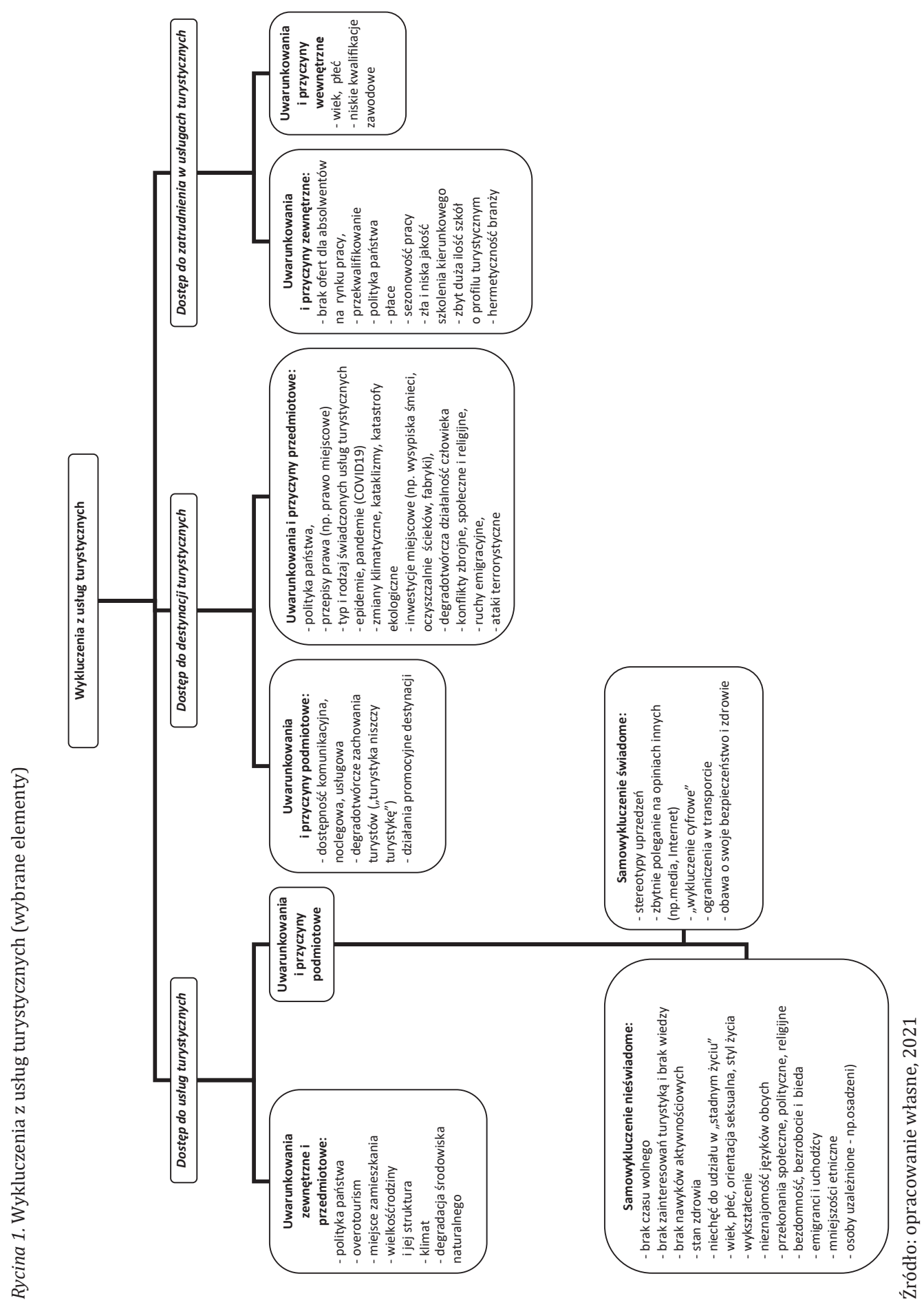


zatrudniania więźniów, co sprzyjało dodatkowo bezczynności i monotonii więziennej” (Poklek, 2008: 59). Według Lapińskiego „zajęcia z zakresu kultury fizycznej i sportu w opinii osób poddanych izolacji penitencjarnej stanowią najbardziej atrakcyjną formę spędzania czasu wolnego. Skazani często wskazują na niewystarczającą częstotliwość tych zajęć podczas odbywania kary pozbawienia wolności oraz na zbyt małą różnorodność" (Lapiński, 2007: 215).

W Raporcie Rady Europy „Education in prison” wskazano na ważną rolę sportu, wychowania fizycznego i kultury fizycznej (w tym i turystyki) w zakresie zagospodarowania czasu wolnego osadzonych, oraz zalecono, aby mieli oni możliwość regularnego uczestniczenia w tego typu zajęciach. W Raporcie zwrócono zwłaszcza uwagę na takie aktywności i zajęcia, jak m.in. kajakarstwo, wędrówki górskie, pływanie itp. (Council of Europe, 1990: 39). Programy te skierowane są zwłaszcza do młodocianych osadzonych.

Również w kolejnym dokumencie UE, „European Prison Rules” wskazano na potrzebę zapewnienia wszystkim więźniom udziału w zajęciach rekreacyjnych, sportowych, kulturalnych, jak i innych formach spędzania czasu wolnego (np. realizacja swojego hobby) (Council of Europe, 2006: 15).

Jeśli chodzi o przykład kraju realizującego ww. zalecenia, to dobrym przykładem jest Szwecja. Według tamtejszej Służby Więziennictwa (szw. Kriminalvården) każdy więzień ma prawo do udziału w zajęciach rekreacyjnych i uprawiania aktywności fizycznej (FARK Fängelse, 2011: 18-19). Przykładem takich ofert skierowanych do więźniów są zajęcia z zakresu sportu, rekreacji i turystyki, realizowane np. w więzieniu w mieście Luleå ${ }^{3}$.

W Polsce w wielu Zakładach Karnych odbywają się zajęcia aktywnościowe skierowane do osadzonych z zakresu sportu, rekreacji, jak również i turystyki. Poniżej (w tabeli 1.) przedstawiono zestawienie wybranych działań wkluczających z zakresu oferty turystycznej skierowanej do osadzonych z różnych zakładów karnych oraz aresztów śledczych w Polsce.

Tabela 1. Zestawienie wybranych działań wkluczających osoby osadzone, realizowane przez zakłady karne oraz areszty śledcze oferujące dostęp do usług turystycznych

\begin{tabular}{|c|c|}
\hline Zakład & Działania \\
\hline $\begin{array}{l}\text { ZK } \\
\text { Łowicz } \\
27.09 .2019\end{array}$ & $\begin{array}{l}\text { Kilkugodzinna wycieczka po Łowiczu (zapoznanie się z walorami turystycznymi, } \\
\text { historycznymi i krajoznawczymi tego miasta), w której wzięło udział kilkunastu } \\
\text { skazanych z łowickiej jednostki penitencjarnej. Zwiedzanie przez edukacyjne spacery jest } \\
\text { organizowane przez kadrę penitencjarną łowickiej jednostki regularnie. }\end{array}$ \\
\hline $\begin{array}{l}\text { ZK } \\
\text { Olsztyn } \\
19.06 .2019\end{array}$ & $\begin{array}{l}\text { Prelekcja skierowana do osadzonych przygotowana przez Mirosława Arczaka (Klub } \\
\text { Turystyki Rowerowej } 4 \text { R z Olsztyna), która miała na celu przybliżenie turystyki } \\
\text { rowerowej jako sposobu na spędzanie wolnego czasu, dbałości o zdrowie, środowisko } \\
\text { naturalne itp. }\end{array}$ \\
\hline $\begin{array}{l}\text { AŚ Świdnica } \\
08.05 .2019\end{array}$ & $\begin{array}{l}\text { Osadzeni w ramach zajęć kultralno-oświatowych i prowadzonego w jednostce programu } \\
\text { ekologicznego (współpraca AS i Nadleśnictwa Świnica) uczestniczyli w wycieczce } \\
\text { turystycznej (lasy o/Modliszowa) w ramach której odbyła się lekcja z zakresu ochrony } \\
\text { przyrody, ekologii i turystyki. Skazani mieli możliwość zaobserwowania niszczycielskich } \\
\text { działań człowieka i negatywnych wymiarów coraz popularniejszego ruchu turystycznego. }\end{array}$ \\
\hline
\end{tabular}

${ }^{3}$ Alltid tid for training, 2021, https://www.kriminalvarden.se/om-kriminalvarden/nyheter/2021/mars/alltid-tid-for-traning/. 


\begin{tabular}{|c|c|}
\hline $\begin{array}{l}\text { ZK Łowicz } \\
11.05 .2019\end{array}$ & $\begin{array}{l}\text { Dla osadzonych zorganizowano wycieczkę po najważniejszych zabytkach Łowicza } \\
\text { (zabytkowe kościoły, pomniki historyczne, plenerowe wystawy). Wycieczka miała } \\
\text { wymiar resocjalizacyjny i była okazją do refleksji dla jej uczestników. Pozwoliła podjąć } \\
\text { próbę stworzenia planu przewartościowania swojego życia i dokonania zmian zgodnych } \\
\text { z normami społecznymi. Ponadto takie wyjścia poza obręb ZK umożliwiają kontakt ze } \\
\text { środowiskiem zewnętrznym, przygotowują skazanych do powrotu do społeczeństwa } \\
\text { i zmniejszają negatywne konsekwencje pobytu w izolacji więziennej. Taka forma zajęć } \\
\text { kulturalno-oświatowych zapewnia też osadzonym, chociażby poprzez spacerowy } \\
\text { charakter wycieczki, rozwój fizyczny, jak również poznawczy dzięki specjalnie dobranym } \\
\text { trasom. }\end{array}$ \\
\hline $\begin{array}{l}\text { AŚ Kielce } \\
10.05 .2019\end{array}$ & $\begin{array}{l}\text { Dla skazanych zorganizowano wyjazd edukacyjny (wycieczkę turystyczną) w ramach } \\
\text { programu resocjalizacyjnego pt. PATRIOCI } 2019 \text { do Muzeum im. Orła Białego } \\
\text { w Skarżysku Kamiennej. Celem było upowszechnianie wśród skazanych wiedzy o jednej } \\
\text { z najważniejszych placówek kulturalnych i atrakcji turystycznych w woj. świętokrzyskim } \\
\text { oraz kształtowanie społecznie pożądanych postaw, w szczególności przestrzegania } \\
\text { porządku prawnego i tym samym powstrzymywania się od powrotu do przestępstwa. }\end{array}$ \\
\hline
\end{tabular}

ZK - Zakład Karny; AŚ - Areszt Śledczy

Źródło: badania własne na podstawie Służba więzienna, 2021, https://www.sw.gov.pl.

\section{Seniorzy}

Jako ciekawy przykład kraju wspierającego turystykę dla seniorów można podać Hiszpanię. Do najważniejszych programów tam realizowanych, z dofinansowaniem Ministerstwa Zdrowia i Polityki Społecznej (hiszp. Ministerio de Empleo y Seguridad Social), zaliczyć można m.in.:

- Program Wyjazdów Wakacyjnych (hiszp. El Programa de Vacaciones para Mayores);

- Program Wyjazdów Uzdrowiskowych (hiszp. El Programa de Termalismo Social) oferta dla osób powyżej 60 roku życia, które wymagają leczenia sanatoryjnego i pobytów w uzdrowiskach;

- Program wyjazdów turystycznych i sanatoryjnych dla osób z niepełnosprawnościami (Turismo y Termalismo para Personas con Discapacidades);

- Program Razem w Święta Bożego Narodzenia (Juntos en Navidad) - celem jest zwalczanie samotności i izolacji seniorów w czasie świąt (wycieczki krajoznawcze oraz zabiegi w uzdrowiskach);

- Program Świat Seniora (Mundo Senior) - realizowany przez hiszpańskie przedsiębiorstwa zrzeszające duże firmy turystyczne oferujące zniżki dla seniorów (za Górska, 2010b: 4).

Przykładami innych krajów na świecie, w których z powodzeniem realizowane są projekty promujące oferty w zakresie silver tourism ( $\mathrm{z}$ ang. srebrna turystyka), są m.in. Chiny i Brazylia. W pierwszym z tych krajów realizowany jest program ofert turystycznych dla seniorów, który organizowany jest przez sieć Uniwersytetów Trzeciego Wieku (UTW). W Chinach znajduje się 30 tysięcy takich uniwersytetów, co sprawia, że jest to kraj z największą liczbą tego typu placówek na świecie (dla porównania, w Polsce funkcjonuje 615 UTW $^{4}$, które również posiadają oferty turystyczne dla seniorów). Oferta wyjazdów obejmuje m.in. wycieczki i wyjazdy połączone z wykładami z różnych dziedzin (np. historia, geografia, biologia, literatura itp.), wraz z obsługą przewodnicką.

\footnotetext{
${ }^{4}$ Federacja Stowarzyszeń Uniwersytetów Trzeciego Wieku, www.federacjautw.pl.
} 
Rycina 2. Strona internetowa europejskiego programu „Calypso"

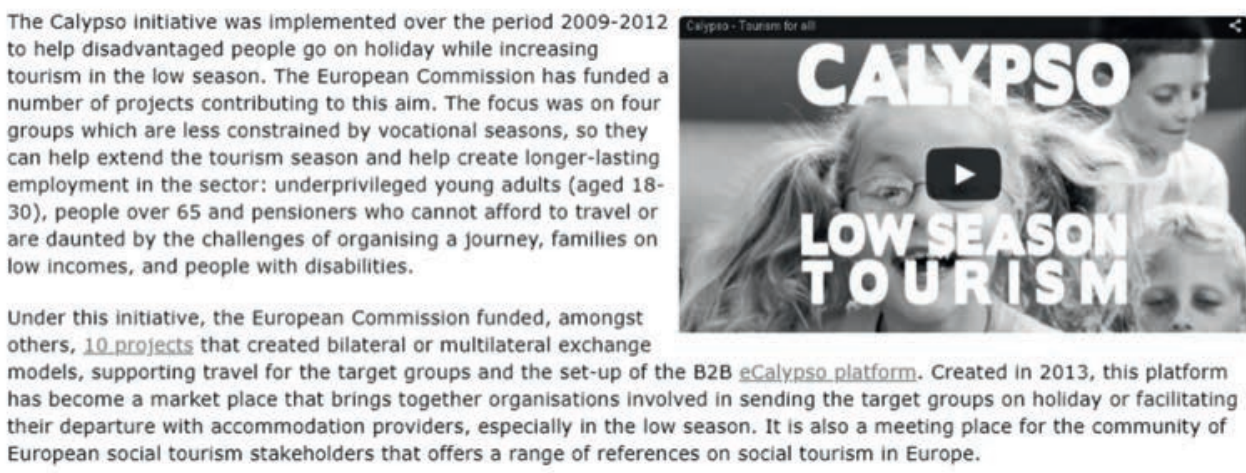

Źródło: www.ec.europa.eu, 2021

Jeden z takich programów realizowany jest w prowincji Shandong, gdzie w zajęciach uczestniczy ponad 500000 studentów-seniorów ${ }^{5}$.

W Brazylii funkcjonuje program Travel at your Best age (z ang., Podróżuj w swoim najlepszym okresie życia), promujący wśród seniorów podróże poza szczytem sezonu6 Program pod nazwą Holiday at your third age (z ang., Wakacje w trzecim wieku) realizowany jest w Chile - z ofertą wyjazdów turystycznych dla seniorów w trakcie średniego i niskiego sezonu, zwłaszcza w destynacje znajdujące się w najbliższym sąsiedztwie zamieszkania seniorów ${ }^{7}$. W Urugwaju działa program wsparcia silver tourism, w ramach którego proponowane są trzydniowe pakiety dla seniorów oraz dofinansowanie ich pobytu ze strony władz centralnych na poziomie 30-60\% (Borzyszkowski, 2017).

W UE duże znaczenie w minimalizowaniu wykluczenia z usług turystycznych ma program Komisji Europejskiej pn. „Calypso - turystyka dla wszystkich”. Poza omawianą grupą społeczną projekt ten, wpisujący się w zagadnienia turystyki społecznej ${ }^{8}$, skierowany jest do osób, które w szczególności z powodów ekonomicznych, społecznych i zdrowotnych mają trudności z dostępnością do turystyki (młodzież, rodziny ubogie i osoby z niepełnosprawnościami). Program realizowany jest m.in. w takich krajach jak Hiszpania, Niemcy, Włochy oraz w Polsce (realizowano projekt „Europe Senior Tourism”, w ramach którego dofinansowuje się wyjazdy w wysokości do 150 euro osobom powyżej 55 roku życia) ${ }^{9}$.

W Polsce również regiony podejmują działania ułatwiające seniorom dostępność do usług turystycznych, a ciekawym przykładem jest program z województwa warmińsko-mazurskiego pn. „Polityka senioralna województwa warmińsko-mazurskiego na

${ }^{5}$ Turystyka na emeryturze: za 10 lat seniorzy będą podróżować dwa razy częściej, 2016, http://www.rynekseniora.pl/polityka_senioralna/104/turystyka_na_emeryturze_za_10_lat_seniorzy_beda_podrozowac_dwa_razy_czesciej,6463.html.

${ }^{6}$ Best Age to Travel, 2016, https://tothenationsworldwide.com/best-age-to-travel/.

${ }^{7}$ https://3rdageholidays.com/.

${ }^{8}$ Przez pojęcie turystyki społecznej rozumie się podróże osób, które w szczególności z powodów ekonomicznych, społecznych i zdrowotnych mają trudności z organizowaniem swoich wakacji (Stasiak, 2010).

${ }^{9}$ Turystyka, 2021, http://www.europarl.europa.eu/factsheets/pl/sheet/126/tourism. 
lata 2014-2020". W jego ramach realizuje się m.in. budowę i dostosowanie obiektów turystycznych i sportowo-rekreacyjnych do potrzeb seniorów; rozbudowę szlaków turystycznych dostępnych dla seniorów; angażowanie seniorów do udziału w przedsięwzięciach turystycznych i rekreacyjnych m.in. w roli przewodników turystycznych; organizację kampanii społecznych dla seniorów na temat korzyści, które wynikają z aktywności turystycznej i sportowo-rekreacyjnej (Zielińska-Szczepkowska, Źróbek-Różańska, 2014: 31-32).

Miastem, które jako jedno z pierwszych zaczęło zwracać uwagę na potrzeby osób starszych, jest Lublin. Od lat prowadzone są tam np. działania mające na celu dostosowanie przestrzeni publicznej do potrzeb seniorów. Realizowana jest coroczna akcja „Miejsca przyjaznego seniorom”, mająca na celu promowanie m.in. rozwiązań architektonicznych ułatwiających seniorom dostęp do atrakcji turystycznych w mieście (np. pochylnie umożliwiające swobodne poruszanie się na wózkach inwalidzkich) (Wysocki, 2015: 63).

Zróżnicowane działania skierowane do seniorów realizowane są również przez Uniwersytety Trzeciego Wieku (UTW), których głównym celem jest poprawa jakości życia osób starszych, ich integracja ze społeczeństwem oraz zagospodarowanie czasu wolnego przez oferowanie im zróżnicowanych zajęć (w tym m.in. spotkania, wykłady tematyczne, zajęcia w sekcjach lub kołach zainteresowań, zajęcia rehabilitacyjne i usprawniające zdrowotnie oraz udział w imprezach kulturalnych, sportowych, rekreacyjnych i turystycznych). Przykładem UTW proponującego osobom starszym zajęcia z zakresu turystyki, jest uniwersytet działający w Gdańsku (UTW AWFiS Gdańsk). Oferta zajęć turystycznych obejmuje organizację wycieczek tematycznych, wyjazdów wypoczynkowych i integracyjnych, zwiedzanie atrakcji turystycznych i instytucji kultury ${ }^{10}$.

Również Ośrodki Pomocy Społecznej realizują działania turystyczne skierowane do seniorów, a jako przykład podać można działania OPS w Sulęcinie, który realizuje Program Wieloletni „Senior+” MRPiPS na lata 2015-2020 (edycja 2018, 2019, 2020). W jego ramach organizowane są m.in. wyjazdy turystyczne, wycieczki oraz oferowane zajęcia wkluczające seniorów poprzez np. zajęcia rehabilitacyjne i ruchowe poprawiające ich sprawność fizyczną, gry i zabawy stymulujące, rekreację, sport, wycieczki ${ }^{11}$.

\section{Osoby z niepełnosprawnościami}

W Europie aż 40\% populacji stanowią osoby w trudnej sytuacji ekonomicznej oraz osoby z niepełnosprawnościami. W związku z problemem niepełnosprawności Unia Europejska kieruje swoje działania na rzecz pomocy tym osobom zgodnie z założeniami Europejskiej Strategii na Rzecz Osób Niepełnosprawnych z roku 2007 (Strategia realizowana jest cyklicznie, obecnie na lata 2021-2030).

Przykładem działań mających na celu walkę z wykluczeniem społecznym osób z niepełnosprawnościami poprzez ich udział w turystyce są działania podejmowane w Niemczech. Działa tam wiele organizacji społecznych, a najpopularniejsze z nich to: Federalne Stowarzyszenie Samopomocowe na rzecz Osób z Niepełnosprawnością

${ }^{10}$ Uniwersytet Trzeciego Wieku Akademii Wychowania Fizycznego i Sportu w Gdańsku, www. utw.awfis.net.

${ }^{11}$ Program Wieloletni „Senior+” MRPiPS na lata 2015-2020. Edycja 2018, 2019, 2020, http://sulecin.naszops.pl/program-wieloletni-senior-mrpips-na-lata-2015-2020-edycja-2018-2019-2020. 
(niem. Federal Self-Hefp Association for People with Disabilities-BSK) oraz Narodowa Agencja Koordynacji w Turystyce (ang. National Tourism Coordination Agency). Organizacje działają w zakresie realizacji wyjazdów turystycznych dla osób z upośledzeniem fizycznym (niepełnosprawnych) (Górska, 2010a: 242-243). Również Niemieckie Linie Kolejowe (niem. Deutsche Bahn) oferują specjalne usługi dla podróżnych z niepełnosprawnościami (np. pociągi wyposażone są w sprzęt, który umożliwia bezpieczne wejście i opuszczenie wagonu, a dworce posiadają podnośniki i rampy, które ułatwiają wsiadanie i wysiadanie z pociągu, natomiast przy korzystaniu z pociągów międzynarodowych osoba z niepełnosprawnością może skorzystać z darmowej pomocy pracowników kolei ${ }^{12}$.

Również polskie miasta starają się realizować działania ułatwiające osobom z niepełnosprawnościami dostępność do usług turystycznych. Takim przykładem może być miasto Chester z Wielkiej Brytanii, które w 2017 roku zostało zwycięzcą w konkursie „Access City Award”, wyróżniającym miasta w pełni dostępne dla turystów z niepełnosprawnościami. Miasto oferuje m.in. udogodnienia w zwiedzaniu miejsc historycznych (rampy, podjazdy, windy, schody ruchome, czytelnie oznakowane atrakcje turystyczne itp. $)^{13}$. Innym miastem wyróżnionym w ww. konkursie jest Rotterdam, gdzie infrastruktura plażowa jest w pełni dostępna dla turystów z niepełnosprawnościami (m.in. udostępnianie bezpłatnych, plażowych wózków inwalidzkich oraz możliwość poruszania się nimi po specjalnie przygotowanej i oznakowanej ścieżce-trasie $)^{14}$.

W Polsce działaniami skierowanymi do osób z niepełnosprawnościami, a umożliwiającymi im uczestnictwo w turystyce, są w m.in. projekty realizowane w regionach. Jako przykład podać można województwo wielkopolskie, gdzie dostępny jest przewodnik „Województwo wielkopolskie - bez barier”. Wydawnictwo ma na celu zachęcenie osób z niepełnosprawnościami do uprawiania turystyki na terenie Wielkopolski i prezentuje trasy, na których zwiedzający nie spotkają się z ograniczającymi ich barierami (turyści mają do swojej dyspozycji 60 tras turystycznych, w tym takie, które można pokonać na wózkach inwalidzkich) ${ }^{15}$.

Również miasta realizują projekty dla osób z niepełnosprawnościami, a ciekawym ich przykładem są te, które podejmuje miasto Łódź. Do działań skierowanych do tej grupy wykluczonych zaliczyć można m.in. „Łódzki standard dostępności” (dostępność do infrastruktury miejskiej); „Kultura dostępna” (oferta 29 jednostek kultury dostępnych do zwiedzania przez turystów z niepełnosprawnościami ${ }^{16}$.

Innym rodzajem działań w omawianym zakresie są te realizowane przez Ośrodki Pomocy Społecznej. Przykładem mogą być działania realizowane przez Miejsko-Gminny Ośrodek Pomocy Społecznej w Sianowie w postaci programu dla osób z niepełnosprawnościami pn. „Program asystent osobisty osoby niepełnosprawnej - edycja 2021". Celem jest wprowadzenie usługi asystenta jako formy ogólnodostępnego wsparcia dla osób z niepełnosprawnościami, posiadających orzeczenie o znacznym lub umiarkowanym stopniu niepełnosprawności. Program ma zapewniać możliwość

${ }^{12}$ Generation 65plus: Angebote, Services und Tipps für Ihre Reise, [b.d.], https://www. bahn.de/p/view/service/60plus/uebersicht.shtml_top-navi-flyout_service-senioren.

${ }^{13} \mathrm{https}: / /$ www.chestercity.com/.

${ }^{14} \mathrm{https}$ ://en.rotterdam.info/about-rotterdam/.

${ }^{15}$ Wielkopolska bez barier, [bd.], http://www.wielkopolska.bezbarier.info.pl/.

${ }^{16}$ https://uml.lodz.pl/niepelnosprawni/. 
skorzystania przez takie osoby z pomocy asystenta przy wykonywaniu codziennych czynności i funkcjonowaniu w życiu społecznym. Usługi asystenta polegają na pomocy osobie z niepełnosprawnością w dotarciu np. do muzeum, teatru, kina, galerii sztuki, na wystawy, jak i na jej udziale w np. wydarzeniach kulturalnych, rozrywkowych, społecznych, sportowych, turystycznych ${ }^{17}$.

\section{Dzieci i młodziè̇}

Do najważniejszych organizacji działających na rzecz rozwoju turystyki młodzieżowej zaliczyć można zwłaszcza Międzynarodową Federację Schronisk Młodzieżowych IYHF (ang. International Youth Hostel Federation). Członkami Federacji są krajowe stowarzyszenia schronisk młodzieżowych, które posiadają co najmniej 5 schronisk, dysponują co najmniej 100 łóżkami oraz udzielają w ciągu roku minimum 5000 noclegów. Dzięki Międzynarodowej Legitymacji młodzież może korzystać z tańszych noclegów i zniżek w schroniskach młodzieżowych w prawie 100 państwach na świecie ${ }^{18}$.

Do europejskich działań sprzyjających turystyce młodych ludzi można zaliczyć również program Erasmus (obecnie Erasmus+), zapoczątkowany w 1987 roku. Programy przyczyniają się do znacznego wzrostu wyjazdów turystycznych młodzieży o charakterze edukacyjnym. Celem programu jest finansowanie wyjazdów studentów na studia do innego kraju europejskiego na okres do jednego roku. Program finansowany jest z budżetu Unii Europejskiej oraz realizowany w 30 krajach członkowskich (w tym w Polsce). Studenci w trakcie swojego pobytu, poza nauką, mogą poznawać również lokalną kulturę, zwyczaje oraz mają szansę zwiedzić nowe miejsca i nawiązać nowe znajomości. Z programów Erasmus oraz Erasmus + skorzystało już 10 mln uczestników ${ }^{19}$ (w tym również młodzież z Polski).

W naszym kraju działaniami wkluczającymi dzieci i młodzież (zwłaszcza w trudnej sytuacji rodzinnej i społecznej) do turystyki i aktywności turystycznych są m.in. programy realizowane przez Ośrodki Pomocy Społecznej. Poniżej przedstawiono wybrane przykłady takich działań:

\section{Ośrodek Pomocy Społecznej w Sulęcinie}

- Wyjazd integracyjno-poznawczy do Wrocławia zrealizowany w ramach Projektu „Aktywna integracja szansą na samodzielność” (05.12.2018). W programie było m.in.: zwiedzanie Panoramy Racławickiej, Afrykarium, Starego Miasta oraz udział w Jarmarku Bożonarodzeniowym. W wyjeździe uczestniczyły dzieci i młodzież z trudnych rodzin;

- Kolonia letnia w Domu Wczasów Dziecięcych w Dusznikach Zdroju. W trakcie pobytu (18-24.07.2016) dzieci poznały wiele atrakcji tego regionu (m.in. Muzeum Papiernictwa, Narodowy Park Gór Stołowych, Błędne Skały). Nieodłączną częścią programu była realizacja zajęć z zakresu szeroko rozumianej profilaktyki oraz zadań ogólnopolskiej kampanii „Zachowaj Trzeźwy Umysł” oraz „Postaw na Rodzinę”;

${ }^{17}$ Asystent osobisty osoby niepełnosprawnej, https://www.mgops.sianow.pl/projekty/ asystent-osobisty-osoby-niepelnosprawnej-edycja-2021/.

${ }^{18} \mathrm{https}: / /$ www.hihostels.com/.

${ }^{19}$ Erasmus+, https://erasmusplus.org.pl/. 
- Wypoczynek letni dla dzieci i młodzieży (17 osób), który był zorganizowany w Ośrodku Wypoczynkowym „Pod Basztą” w Lubniewicach (25-30.07.2016),

- Kolonie letnie w Ośrodku Rekreacyjnym Wielkopolska S.A. Rudno, w którym wzięło udział 15 dzieci z rodzin patologicznych (01-14.08.2016) 20.

Ośrodek Pomocy Społecznej w Staszowie

W lipcu 2019 roku zrealizowano wyjazdy na kolonie w miejscowości Okuninki w OW Świtezianka (Pojezierze Łęczyńsko-Włodawskie), w których udział wzięło 50 dzieci i młodzieży (7-16 lat z rodzin będących w trudnej sytuacji materialnej). W trakcie pobytu uczestniczyli w wielu wycieczkach turystycznych, m.in. do Lublina, Chełma, Włodawy oraz w zajęciach profilaktycznych i kulturalno-oświatowo-rekreacyjnych ${ }^{21}$.

\section{Miejsko-Gminny Ośrodek Pomocy Społecznej w Sianowie}

Ośrodek planuje zorganizować w sierpniu 2021 roku wyjazd kolonijny dla dzieci, które są jego podopiecznymi. Oferta skierowana jest do dzieci i młodzieży objętej pieczą zastępczą, dzieci z rodzin wielodzietnych (troje i więcej dzieci), dzieci wychowywanych przez samotnych rodziców, dzieci z zaburzeniami somatycznymi potwierdzonymi zaświadczeniem lekarskim oraz dzieci zamieszkujących w środowisku ekologicznie zagrożonym $^{22}$.

Jednocześnie dzieci i młodzież z rodzin zagrożonych patologią mogą korzystać w okresie wakacji letnich z wyjazdów organizowanych przez Caritas Polska - jego oddziały diecezjalne, jak również duszpasterstwa parafialne. W ramach programu „Wakacyjna Akcja Caritas" w roku 2019 z wypoczynku wakacyjnego skorzystało 25000 dzieci z ubogich rodzin ${ }^{23}$. Do częstszych wyjazdów dzieci przyczynił się w pewnym stopniu również wprowadzony w 2016 roku Program 500+, ponieważ w roku 2018 odnotowano 20-procentowy wzrost wyjazdów turystycznych tej grupy ${ }^{24}$.

W regionach także realizowane są działania skierowane do dzieci i młodzieży. Przykładem może być program z województwa śląskiego pn. \#OdkryjSlaskie, mający na celu zachęcenie dzieci i młodzieży do uczestnictwa w turystyce. Projekt powstał z myślą o zagospodarowaniu czasu wolnego dzieci i młodzieży poprzez zapewnienie im dostępu do aktywności turystycznych (wycieczki, obozy, biwaki itp.), dzięki którym mogą spędzić czas aktywnie i poznać własny region. Wsparcie otrzymają organizatorzy turystyki, przede wszystkim na organizację wycieczek szkolnych wraz z usługami przewodnickimi. Aby otrzymać wsparcie finansowe, wymagana jest organizacja wycieczki autokarowej z przynajmniej jednym noclegiem, pełnym wyżywieniem i usługą

${ }^{20}$ Wypoczynek letni dzieci i młodzieży, 2016, http://sulecin.naszops.pl/aktualnosci-1/n,wypoczynek-letni-dzieci-i-mlodziezy.

${ }^{21}$ Wyjazd na kolonie 2019, 2019, http://ops.staszow.pl/wyjazd-na-kolonie-2019.html.

${ }^{22}$ Wypoczynek letni dzieci i młodzieży 2021 r., 2021, https://www.mgops.sianow.pl/wypoczynek-letni-dzieci-i-mlodziezy-2021r/.

${ }^{23}$ Roczne sprawozdanie merytoryczne z działalności organizacji pożytku publicznego, 2020, https://caritas.pl/wp-content/uploads/2021/06/sprawozdanie-merytoryczne-2019.pdf.

${ }^{24}$ Ministerstwo Rodziny i Polityki Społecznej, 2019, https://www.gov.pl/web/rodzina/rodzina-500-plus. 
przewodnicką, która obejmie minimum 5 atrakcji turystycznych na terenie województwa śląskiego. Wsparcie udzielane jest $\mathrm{w}$ formie dotacji celowej dla gmin ${ }^{25}$.

Również miasta realizują swoje działania proturystyczne, skierowane do najmłodszych będących w trudnej sytuacji społecznej. Władze miasta Jaworzno corocznie dofinansowują wyjazdy wakacyjne dla dzieci i młodzieży. W 2019 miasto przeznaczyło na ten cel 200000 zł. Zrealizowano m.in. następujące działania: a) dzieci i młodzież należące do OSP „Ciężkowice” wyjechały na wakacje na Mazury; b) Parafia pw. Elżbiety Węgierskiej w Jaworznie zorganizowała kolonię w Karpaczu dla 50 dzieci w wieku od 6 do 16 lat; c) Katolickie Stowarzyszenie Rodzin Wielodzietnych zrealizowało wyjazd wakacyjny dla 50 osób z rodzin wielodzietnych do Lewina Kłodzkiego w Górach Stołowych (w ramach zadania „Zdobądź Szczyty”) 26.

\section{WNIOSKI}

W świetle przeprowadzonych badań można sformułować następujące wnioski:

- rozwijający się od wielu lat „przemysł turystyczny” nie jest wolny od zjawisk dotychczas mało znanych, a mianowicie „wykluczeń” z dostępu do usług turystycznych - nie tylko jednostek, ale i całych zróżnicowanych grup społecznych;

- wykluczenie z turystyki to zjawisko wielowymiarowe, nasilające się również w krajach, które wcześniej nie borykały się z takimi problemami (spowodowane jest to m.in. pojawianiem się niekorzystnych przemian społeczno-gospodarczo-politycznych, pogłębiającymi się nierównościami i rozwarstwieniem społecznym);

- wykluczenia społeczne zauważalne są w wielu typach i formach podejmowanych aktywności turystycznych (jako np. bariery, ograniczenia) i można zdefiniować je w kilku obszarach: dostępności do usług turystycznych, dostępności do destynacji oraz dostępności do pracy w sektorze turystycznym;

- wykluczenia z usług turystycznych obejmują coraz liczniejsze społeczności w wielu krajach, w tym także w Polsce (m.in. wybrane do badań grupy, tj. osoby osadzone, seniorów, dzieci i młodzież oraz osoby z niepełnosprawnościami).

Na szczęście pomocą dla tych grup społecznie wykluczonych mogą być zróżnicowane i coraz liczniejsze programy i projekty, realizowane i oferowane przez różne instytucje, organizacje, jak i podmioty powołane do skutecznego „wkluczania społecznego przez turystykę i do turystyki".

Jednocześnie należy mieć nadzieję, że te wielorakie działania pomocowe skierowane do ww. grup staną się dla wielu innych inspiracją do dalszych lub nowych inicjatyw w tym zakresie.

\section{Literatura}

\section{References}

3rdAgeHolidays.com. [b.d.]. Pozyskano z https://3rdageholidays.com/ (dostęp 26.08.2021).

Alejziak, W. (2007). Inhibitory aktywności turystycznej: teoretyczne i metodologiczne aspekty studiów nad ograniczeniami i barierami uczestnictwa w wyjazdach wypoczynkowych. Folia Turistica, 18, 59-87.

Alejziak, W. (2011). Aktywność turystyczna: międzynarodowe i krajowe zróżnicowanie oraz kwestia wykluczenia społecznego. Turyzm, 21, 7-16.

\footnotetext{
${ }^{25}$ Śląski pakiet dla turystyki, [b.d.], https://dlaturystyki.slaskie.pl/.

${ }^{26}$ https://jaworzno.naszemiasto.pl/.
} 
Alltid tid for training. (2021, 26 marca). kriminalvarden.se. Pozyskano z https://www.kriminalvarden.se/om-kriminalvarden/nyheter/2021/mars/alltid-tid-for-traning/ (dostęp 26.08.2021).

Asystent osobisty osoby niepełnosprawnej. [b.d.]. Miejsko-Gminny Ośrodek Pomocy Społecznej $w$ Sianowie. Pozyskano z https://www.mgops.sianow.pl/projekty/asystent-osobisty-osoby-niepelnosprawnej-edycja-2021/ (dostęp 16.09.2021).

Becker-Pestka, D., Kubiński, G., Łojko, M. (2017). Różne obszary wykluczenia społecznego w Polsce. Wybrane zagadnienia. Wrocław: Exante.

Best Age to Travel. (2016, 14 kwietnia). Pozyskano z https://tothenationsworldwide.com/best-age-to-travel/ (dostęp 15.09.2021).

Borzyszkowski, J. (2017). Polityka turystyczna na rzecz seniorów. Przegląd wybranych praktyk. Toruń: Politechnika Koszalińska.

Bowles, P. (2010). The Sheltering Sky. Camberwell: Penguin.

Canestrini, D. (2016). Evolución del Homo turisticus. Revista CIDOB d' Afers Internacionals, 113, 149-159.

Chestercity.com. [b.d.]. Pozyskano z https://www.chestercity.com/ (dostęp 26.08.2021).

Council of Europe. (1990). Education in prison. Report. Pozyskano z: https://www.epea.org/wp-content/uploads/Education_In_Prison.pdf (dostęp 28.08.2021).

Council of Europe. (2006). European Prison Rules. Strasbourg: Council of Europe Publishing. Pozyskano z https://rm.coe.int/european-prison-rules-978-92-871-5982-3/16806ab9ae (dostęp 28.08.2021).

Council of Europe. Committee of Ministers. (1989, 13 października). Of the committee of ministers to member states on education in prison. Recommendation No. R (89) 12. Pozyskano z https://rm.coe.int/09000016804c858f (dostęp 28.08.2021).

D’Ambrosio, C., Gradin, C. (2003). Income Distribution and Social Exclusion of Children. Evidence from Italy and Spain in the 1990s. Journal of Comparative Family Studies, 34(3), 479-494.

Erasmus+. [b.d.]. Fundacja Rozwoju Systemu Edukacji. Pozyskano z https://erasmusplus.org.pl/ (dostęp 13.09.2021).

Europa w 12 lekcjach. (2006). Komisja Europejska. Bruksela: Urząd Publikacji UE.

Europejska Konferencja Ministerialna „Turystyka dla wszystkich”. (2001, 1-2 lipca). Brugia (Belgia). Pozyskano z http://eur-lex.europa.eu (dostęp 28.08.2021).

FARK Fängelse. (2011, 10 stycznia). Kriminalvårdens författningssamling. Kriminalvårdens föreskrifter och allmänna råd om fängelse. Pozyskano z https://www.kriminalvarden.se/globalassets/om_oss/lagar/fark-fangelse-konsoliderad-2020_4.pdf (dostęp 14.09.2021).

Federacja Stowarzyszeń Uniwersytetów Trzeciego Wieku. Pozyskano z www.federacjautw.pl (dostęp 26.08.2021).

General Assembly of the World Tourism Organization. (1999). Global Code of Ethics For Tourism [Globalny Kodeks Etyki w Turystyce]. UNWTO.org. Pozyskano z https://www.unwto.org/ global-code-of-ethics-for-tourism (dostęp 28.08.2021).

Generation 65plus: Angebote, Services und Tipps für Ihre Reise. [bd.]. Pozyskano z https:// www.bahn.de/p/view/service/60plus/uebersicht.shtml_top-navi-flyout_service-senioren (dostęp 26.08.2021).

Goeldner, C.R., Ritchie, J.R.B. (2003). Tourism: Principles, Practices, Philosophies. [wydanie 9]. New York, Chichester: Wiley.

Golinowska, S., Broda-Wysocki, P. (2005). Kategorie ubóstwa i wykluczenia społecznego. Przegląd pojęć. W: S. Golinowska, E. Tarkowska, I. Topińska (red.), Ubóstwo i wykluczenie społeczne. Badania. Metody. Wyniki. Warszawa: Instytut Pracy i Spraw Socjalnych, 32-35.

Górska, E. (2010a). Promocja turystyki społecznej jako element walki z wykluczeniem społecznym. W: Ubóstwo i wykluczenie. Wymiar ekonomiczny, społeczny i ekonomiczny. Warszawa: Bramasole Public Relations \& Publishing House, 242-243.

Górska, E. (2010b). Turystyka społeczna jako forma aktywizacji rynków turystycznych na przykładzie programów turystyki społecznej w Hiszpanii. Acta Scientiarum Polonarum. Oeconomia, 4, 136-137.

Gracz, J. Sankowski, T. (2001). Psychologia w rekreacji i turystyce. Poznań: AWF.

Hihostels.com. [b.d.]. Pozyskano z https://www.hihostels.com/ (dostęp 26.08.2021).

Jaworzno.naszemiasto. Pozyskano z https://jaworzno.naszemiasto.pl/ (dostęp 15.09.2021). 
Komisja Europejska. Pozyskano z www.ec.europa.eu (dostęp 26.08.2021).

Lapiński, P. (2007). Wybrane dylematy moralne dotyczące podejmowania aktywności fizycznej przez osoby odbywające karę pozbawienia wolności. Aktywność Ruchowa Ludzi w Różnym Wieku, 11(2), 215-221.

Łódź.pl. Pozyskano z https://uml.lodz.pl/niepelnosprawni/ (dostęp 15.09.2021).

Łuszczyńska, M. (2011). Turystyka rodzin znajdujących się w złożonej sytuacji społecznej - uwarunkowania i wyzwania. W: A. Stasiak (red.), Perspektywy i kierunki rozwoju turystyki społecznej w Polsce. Łódź: Wydawnictwo WSTiH, 171-195.

Ministerstwo Gospodarki, Pracy i Polityki Społecznej. (2003). Narodowa Strategia Integracji Społecznej dla Polski. Pozyskano z https://www.ipiss.com.pl/wp-content/uploads/downloads/2012/08/nsis_2000.pdf.

Ministerstwo Rodziny i Polityki Społecznej. (2019, 25 czerwca). Rodzina 500 plus. Pozyskano z https://www.gov.pl/web/rodzina/rodzina-500-plus (dostęp 26.08.2021).

Olszewski-Strzyżowski, D.J. (2017). Działania w zakresie sportu, rekreacji i turystyki realizowane przez ośrodki pomocy społecznej w Polsce jako pomoc osobom wykluczonym - bezrobotnym. Studia Periegetica, 3, 79-97.

Opinia Europejskiego Komitetu Ekonomiczno-Społecznego w sprawie turystyki socjalnej w Europie. 2006/C 318/12. Dz.U. UE z 23.12.2006.

Płocka, J. (2009). Turystyka. Wybrane zagadnienia. Toruń: Wydawnictwo Escape Magazine.

Poklek, R. (2008). Historyczne uwarunkowania penitencjarnej kultury fizycznej. Aktywność Ruchowa Ludzi w Różnym Wieku, 12, 55-61.

Program Wieloletni „Senior+” MRPiPS na lata 2015-2020. Edycja 2018, 2019, 2020. Pozyskano z http://sulecin.naszops.pl/program-wieloletni-senior-mrpips-na-lata-2015-2020-edycja2018-2019-2020 (dostęp 29.08.2021).

Raczkowska, M., Gruziel, K. (2018). Ubóstwo i wykluczenie społeczne w Unii Europejskiej w relacji miasto-wieś. Zeszyty Naukowe SGGW. Polityki Europejskie, Finanse i Marketing, 20, 172185.

Roczne sprawozdanie merytoryczne z działalności organizacji pożytku publicznego. (2020, 13 października). Narodowy Instytut Wolności - Centrum Rozwoju Społeczeństwa Obywatelskiego. Pozyskano z https://caritas.pl/wp-content/uploads/2021/06/sprawozdanie-merytoryczne-2019.pdf (dostęp 15.09.2021).

Rotterdam.info. Pozyskano z https://en.rotterdam.info/about-rotterdam/ (dostęp 15.09.2021).

Służba Więzienna. Pozyskano z https://www.sw.gov.pl (dostęp 26.08.2021).

Stasiak, A. (2010). Cele i zadania turystyki społecznej - kilka uwag o istocie zjawiska. W: A. Stasiak (red.), Turystyka społeczna w regionie łódzkim. Łódź: Wydawnictwo WSTH.

Śląski pakiet dla turystyki. [b.d.] Samorząd Województwa Śląskiego. Pozyskano z https://dlaturystyki.slaskie.pl/ (dostęp 15.09.2021).

Turystyka na emeryturze: za 10 lat seniorzy będą podróżować dwa razy częściej. (2016, 17 sierpnia). Pozyskano z http://www.rynekseniora.pl/polityka_senioralna/104/turystyka_na_ emeryturze_za_10_lat_seniorzy_beda_podrozowac_dwa_razy_czesciej,6463.html. (dostęp 15.09.2021).

Turystyka. (2021, maj). Pozyskano z http://www.europarl.europa.eu/factsheets/pl/sheet/126/ tourism (dostęp15.09.2021).

Uniwersytet Trzeciego Wieku Akademii Wychowania Fizycznego i Sportu w Gdańsku. Pozyskano z www.utw.awfis.net. (dostęp 26.08.2021)

Urry, J. (2007). Spojrzenie turysty. Warszawa: Wydawnictwo Naukowe PWN.

Ustawa z dnia 24 listopada 2017 r. o imprezach turystycznych i powiązanych usługach turystycznych. Dz.U. z 2017 r. poz. 2361 ze zm.

Wielkopolska bez barier. [b.d.]. Pozyskano z http://www.wielkopolska.bezbarier.info.pl/ (dostęp 26.08.2021).

Winiarski, R. (2011). Rekreacja i czas wolny. Studia humanistyczne. Warszawa: Oficyna Wydawnicza ŁOŚGRAF.

Wyjazd na kolonie 2019. (2019, 16 czerwca). Pozyskano z http://ops.staszow.pl/wyjazd-na-kolonie-2019.html (dostęp 15.09.2021). 
Wypoczynek letni dzieci i młodzieży 2021 r. (2021, 23 czerwca). Miejsko-Gminny Ośrodek Pomocy Społecznej w Sianowie. Pozyskano z https://www.mgops.sianow.pl/wypoczynek-letni-dzieci-i-mlodziezy-2021r/ (dostęp 26.08.2021).

Wypoczynek letni dzieci i młodzieży. (2016, 14 września). Pozyskano z http://sulecin.naszops. pl/aktualnosci-1/n,wypoczynek-letni-dzieci-i-mlodziezy (dostęp15.09.2021).

Wysocki, M. (2015). Przestrzeń Publiczna Przyjazna Seniorom. Warszawa: Biuro Rzecznika Praw Obywatelskich.

Zielińska-Szczepkowska, J., Źróbek-Różańska, A. (2014). Aktywność władz samorządowych w obliczu zmian demograficznych kształtujących sektor turystyczny. Przykład województwa warmińsko-mazurskiego. Zeszyty Naukowe Uniwersytetu Szczecińskiego. Studia i Prace Wydziału Nauk Ekonomicznych Zarządzania, 3(37), 315-323.

Dariusz Jacek Olszewski-Strzyżowski, dr hab., prof., Akademia Wychowania Fizycznego i Sportu w Gdańsku, Wydział Kultury Fizycznej, Katedra Wychowania Fizycznego i Nauk Społecznych, Zakład Zarządzania i Marketingu. Zainteresowania naukowe autora skupiają się m.in. na zjawiskach wykluczeń społecznych w turystyce oraz w sporcie.

Dariusz Jacek Olszewski-Strzyżowski, habilitated doctor, professor of the Gdansk University of Physical Education and Sport, Department of Physical Education and Social Sciences, Department of Management and Marketing. The author's research interests focus, among others, on the phenomena of social exclusion in tourism and sport.

ORCID: https://orcid.org/0000-0001-7179-2808

\section{Adres/address:}

Akademia Wychowania Fizycznego i Sportu w Gdańsku

ul. Kazimierza Górskiego 1

80-336 Gdańsk

e-mail: dariusz.olszewski@awf.gda.pl 